\title{
TREATMENT OF MUTUAL FUNDS UNDER ERISA
}

\author{
WILLIAM M. TARTIKOFF*
}

Perhaps no statute enacted by Congress in recent years has caused as much concern to the financial community as the Employee Retirement Income Security Act of 1974 (ERISA). ${ }^{1}$ The Act, which prohibits certain transactions involving fiduciaries, parties in interest and disqualified persons of employee benefit plans, has particularly troubled financial imstitutions. Within six months after the effective date of the Act, representatives of various financial industries urged Congress to amend substantially the Act's provisions relating to prohibited transactions. ${ }^{2}$ The Act, however, has not provoked such a vocal response from open-end inanageinent investinent coinpanies, commonly known as inutual funds. The primary reason that inutual funds have not responded so heatedly is that ERISA insulates thein froin the prohibited transaction probleins confronting other segnents of the financial coinmunity and has served to encourage plan mvestment in inutual fund shares. This Article will discuss the special treatment that ERISA accords mutual fund organizations and the relevant administrative developments that have occurred since the passage of the Act.

Any analysis of this inatter inust begin with a description of the detailed regulatory scheme imposed on mutual fund organizations by the federal securities laws. This systen of regulation led Congress to accord special treatment to mutual funds under ERISA.

* Assistant Counsel of the Investment Company Institute, the national association of the American mutual fund industry. The views expressed in this Article are those of the author and do not necessarily represent those of the Institute.

THE FOLLOWING CITATIONS WILL BE USED IN THIS ARTICLE:

Employee Retirement Income Security Act of 1974, Pub. L. No. 93-406, 88 Stat. 829 (codified in scattered sections of $5,18,26,31,42$ U.S.C.) [heremafter cited by session law sections of ERISA];

H.R. CONF. REP. No. 1280, 93d Cong., 2d Sess., reprinted in [1974] U.S. CODE CONG. \& AD. News 5038 [hereinafter cited as H.R. CONF. REP.].

1. ERISA $\S \S 1-4082$.

2. See Oversight of the Employee Retirement Income Security Act of 1974: Hearings on Pub. L. 93-406 Before the Subcomm. on Labor Standards of the House Comm. on Education and Labor, 94th Cong., Ist Sess. 440, 496, 669 (1975) (statements of Bernard F. Curry on behalf of the American Bankers Association, Mark N. Kaplan on behalf of the Securities Industry Association and William C. Morton, Jr., on behalf of the Association for Advanced Life Underwriting). 


\section{Structure and Regulation of Mutual Fund ORGANIZATIONS ${ }^{3}$}

A mutual fund complex usually consists of three distinct entities: the mutual fund, the investment adviser and the principal underwriter. First, the mutual fund, usually im corporate form, sells its own shares to the public and uses the proceeds to acquire securities that ineet the fund's particular investment objectives, for example, growth and imcome. Second, the imvestment adviser, a separate entity, provides investment advice and other services to the mutual fund pursuant to a written contract. Third, a principal underwriter, pursuant to a written contract, usually arranges for the distribution of the fund's shares to the public. Often the investinent adviser and principal underwriter are the same entity or are subject to common control. The principal underwriters for inost funds whose shares are sold with a sales charge arrange for public distribution through independent broker-dealers; however, the shares of a few funds, including the largest, are sold by salesmen employed by the principal underwriter. Funds without a sales charge, commonly referred to as "no-load" funds, deal directly with the public in the sale of their shares, although some no-load funds technically sell their shares through principal underwriters.

Mutual funds are subject to extensive regulation under the federal securities laws. In the words of a fornner chairman of the Securities and Exchange Commission (SEC), "No issuer of securities is subject to more detailed regulation than mutual funds." 4 Since nost inutual funds offer their shares to investors on an ongoing basis, the mutual funds must continuously register such shares under the Securities Act of $1933^{5}$ and must provide current prospectuses to investors. Investment advisers to mutual funds must register with the SEC under the Investment Advisers Act of $1940,{ }^{6}$ and principal underwriters must register as broker-dealers under the Securities Exchange Act of 1934.? Most significantly, mutual funds are subject to detailcd substantive reg-

3. For a more detailed discussion, see House Comm. on INTERstate and Foreign Commerce, Report of Securities and Exchange Commission on the Public Policy Implications of INVESTMENT CoMpanY Growth, H.R. Rep. No. 2337, 89th Cong., 2d Sess. 4572 (1966).

4. Letter from SEC Chairman Ray Garrett, Jr., to Senator John Sparkman (Nov. 4, 1974), quoted in Freeman, Marketing Mutual Funds and Individual Life Insurance, 28 S.C.L. REv. 1, 77 (1976). Freeman summarized the situation in more colorful terms: "[T]he mutual fund industry has been studied, criticized, hitigated against, and force-fed legislative and regulatory cure-alls to a fare-thee-well." Id.

5. 15 U.S.C. $\$ 877 \mathrm{a}-77 \mathrm{aa}$ (1976).

6. $I d . ~ \$ \S 80 \mathrm{~b}-1$ to -21 .

7. Id. $\S \S 78 \mathrm{a}-78 \mathrm{kk}$. 
ulation under the Investment Company Act of $1940 .{ }^{8}$ That Act contains numerous provisions designed to prevent self-dealing, maintain the fund's independence and prevent the payment of excessive fees and charges by the inutual fund and its shareholders. Sections 10, 15, 17 and 36 of the Act contain several very important provisions: section 10 requires a inutual fund to have independent directors; ${ }^{9}$ section 15 relates to approval of the fund's advisory and underwriting contracts; ${ }^{10}$ section 17 prohibits certain affiliated transactions; ${ }^{11}$ and section 36 deals with fiduciary duties. ${ }^{12}$

\section{Prohibited Transactions Under ERISA}

Section 406 of ERISA and parallel section 4975(c)(1) of the Internal Revenue Code of 1954 (the Code) set forth a laundry hist of transactions that are prohibited unless the transactions are exeinpted by statute, covered by a statutory transitional provision or exempted administratively by the Department of Labor and the Internal Revenue Service (the Agencies). ${ }^{13}$ The laundry list of prohibited transactions includes transactions between an einployee benefit plan and a "party in interest" or a "disqualified person."14 These two terms are broadly defined to include any fiduciary, ${ }^{15}$ einployer, employee organization or person providing services to the plan. ${ }^{16}$ The prohibited transactions between a plan and a party in interest or disqualified person include, inter alia, sales, exchanges, furmishing of goods or services and transfers of plan assets. ${ }^{17}$ In addition, there are special prohibitions on self-dealing

\footnotetext{
8. Id. $\$ \S 80 \mathrm{a}-1$ to -52 .

9. Id. $\$ 80 \mathrm{a}-10$.

10. Id. $\$ 80 \mathrm{a}-15$.

11. Id. $\$ 80 \mathrm{a}-17$.

12. Id. $\$ 80 \mathrm{a}-36$.

13. See ERISA § 406; I.R.C. $\$ 4975$ (c)(1). Under Reorganization Plan No. 4 of 1978, 43 Fed.
} Reg. 47,713 (1978) (effective Dec. 31, 1978), the authority of the Secretary of the Treasury to issue rulings and exemptions under I.R.C. $\$ 4975$, with certain exceptions not relevant to this Article, has been transferred to the Secretary of Labor.

14. ERISA § 406; I.R.C. § 4975(c)(1).

15. ERISA $\S 3(21)(A)$ and I.R.C. $\S 4975(e)(3)$ set forth a three-part definition of "fiduciary" as a person who:

(A) exercises any discretionary authority or discretionary control respecting management of such [employee benefit] plan or exercises any authority or control respecting management or disposition of its assets,

(B) renders investunent advice for a fee or other compensation, direct or indirect, with respect to any moneys or other property of such plan, or has authority or responsibility to do so, or

(C) has any discretionary authority or discretionary responsibility in the adminisId. tration of such plan.

16. ERISA § 3(14); I.R.C. $\$ 4975(\mathrm{e})(2)$.

17. ERISA § 406; I.R.C. § 4975(c)(1). 
by fiduciaries. ${ }^{18}$ The prohibited transaction provisions, combimed with the broad statutory definitions of party in interest, ${ }^{19}$ disqualified person $^{20}$ and fiduciary, ${ }^{21}$ have presented many problems for all persons connccted with employee benefit plans, mcluding employers, unions, trustees, administrators, consultants and various funding inedia.

ERISA and the Code contain specific exemptive provisions relating to particular types of financial organizations mcluding banks and insurance companies. These statutory provisions are cast in terms of "transactional exemptions": they permit a bank or insurance company that is a party in interest or disqualified person with respect to a plan to enter into otherwise prohibited transactions with the plan. ${ }^{22}$ The transactional exemption approach offers to those financial institutions covered by the provisions the obvious advantage of explicit statutory authorization for the enumerated activities. This approach, however, poses the risk that activities that fail to conform precisely to the statutory language may be deemed prohibited transactions. Moreover, the listing of exempt transactions may threaten banks and insurance coinpanies with restriction of their overall scope of action by operation of the principle of inclusio unius est exclusio alterius: the enumeration of a series of exempt transactions inay inply that other transactions are prohibited.

\section{Mutual Fund Provisions of ERISA}

ERISA's approach to mutual funds differs greatly from its approach to banks and insurance companies. Instead of presuming the relationship of a party in interest or disqualified person and then exempting certain transactions, ERISA decrees that the normal relationship of a mutual fund and an employee benefit plan, in which the mutual fund merely serves as a funding vehicle for the plan, will protect the mutual fund, its investment adviser and its primcipal underwriter from being defined as a fiduciary, party im interest or disqualified person. $^{23}$

18. ERISA § 406(b).

19. ERISA \& 3(14).

20. I.R.C. $\$ 4975(\mathrm{e})(2)$.

21. ERISA \& 3(21); I.R.C. \& 4975(e)(3).

22. For example, ERISA § 408(b)(6) and I.R.C. $\S 4975$ (d)(6) permit a bank that is a fiduciary with respect to a plan to render an "ancilliary" service to the plan in certain circumstances. Similarly, ERISA § 408(b)(4)-(5) and I.R.C. § 4975(d)(4)-(5) permit a plan covering employees of a bank or insurance company to invest under certain conditions in the deposits of such bank or the insurance policies of such company. In specified circumstances, ERISA $\S 408(b)(8)$ and I.R.C. $\S 4975(d)(8)$ permit a plan to purcliase or sell interests in a pooled fund maimtained by a bank or insurance company.

23. ERISA $\S \S 3(21)(B), 401(b)(1)$. See text immediately following this note. 
This definitional approach derives from two statutory provisions. Section 401(b)(1) of ERISA provides:

In the case of a plan which invests in any security issucd by an investment company registered under the Investment Company Act of 1940, the assets of such plan shall be deemed to imclude such security but shall not, solely by reason of such investment, be deemed to include any assets of such investment company. ${ }^{24}$

Section 3(21)(B) of ERISA provides:

If any money or other property of an einployee benefit plan is invested in securities issued by an investment company registered under the Investment Company Act of 1940, such investment shall not by itself cause such investment company or such investment company's investınent adviser or principal underwriter to be deemed to be a fiduciary or a party in interest as those terms are defined in this title, except insofar as such investment company or its investinent adviser or principal underwriter acts in counection with an einployee benefit plan covering einployees of the investment company, the investinent adviser, or its principal underwriter. ${ }^{25}$

The legislative history of ERISA indicates that Congress enacted these provisions recognizing that inutual fund organizations are already subject to extensive fiduciary regulation under the federal securities laws. ${ }^{26}$

24. ERISA § 401(b)(1).

25. ERISA $\S 3(21)$ (B). 1.R.C. $\$ 4975(\mathrm{e})(8)$ contains similar language, but uses the term "disqualified person" rather than ERISA's term "party in interest."

26. See, e.g., H.R. Conf. Rep. 296. The Report states:

Since mutual funds are regulated by the Investment Coinpany Act of 1940 and, since (under the Internal Revenue Code) mutual funds inust be broadly held, it is not considered necessary to apply the fiduciary rules to mutual funds merely because plans invest $\mathrm{m}$ their shares. Therefore, the substitute provides that the mere mvestment by a plan in the shares of a mutual fund is not to be sufficient to cause the assets of the fund to be considered the assets of the plan. (However, a plan's assets will mclude the shares of a inutual fund held by the plan.)

The substitute also provides that a inutual fund is not to be considered a fiduciary or a party-in-interest merely because a plan invests in its shares, except that the mutual fund may be a fiduciary or party-in-imterest if it acts in connection with a plan covering the einployees of the investment company, the investment adviser, or its primcipal underwriter.

Id. Earlier committee reports contained similar explanations. See, e.g., SENATE COMM. ON FInance, Private Pension Plan Reform, S. Rep. No. 383, 93d Cong., 1st Sess. 103 (1973), reprinted in [1974] U.S. CODE CONG. \& AD. NEWS 4890, 4986-87; SUBCOMM. ON LABOR OF THE Senate Comm. on Labor and Public Welfare, 94Th Cong., 2d Sess., Legislative History of the Employee Retirement InCome Security ACt of 1974, Pub. L. No. 93-406, at 3306 (Comm. Print 1976).

The latter report states:

Also, in addition, the bill provides that an open-end nutual fund, the mutual fund's investment advisers, and the inutual fund's principal nnderwriters are not to be considered as plan fiduciaries or parties in interest inerely because an employee benefit trust purchases shares in the mutual fund. Mutual funds are currently subject to substantial restrictions on transactions with affiliated persons under the Investment Coinpany Act of 1940, and also it appears that unintended results might occur (such as presenting [sic] a trust froin redeeming its inutual fund shares) if mutual funds were not excluded from these definitions. 
These provisions of ERISA have msulated mutual funds from the major problems of prohibited transactions that confront other investment media. ${ }^{27}$ Therefore, while representatives of other financial industries have requested remedial legislation in this area, ${ }^{28}$ the mutual fund industry has not felt the need to request such legislation. ${ }^{29}$

\section{ADMINISTRATIVE EXEMPTIONS}

Although ERISA generally exempts mutual fund organizations from classification as fiduciaries, parties in interest or disqualified persons, the mutual fund industry has identified five situations that may fall outside the scope of the statutory exemptions. The industry has, therefore, filed five applications with the Agencies seeking class exemptions. ${ }^{30}$ In some of the cases there was considerable doubt whether the transaction im issue was in fact prohibited. Only one case posed any risk of seriously disrupting ordmary dealings between mutual fund organizations and employee benefit plans. Yet, as the following summary indicates, the Agencies have granted all but one of the class exemptions sought by the mutual fund industry.

\section{A. A Mutual Fund Organization's Internal Plan.}

It is common practice for a mutual fund complex to fund an employee benefit plan covering its own employees with shares of one or more mutual funds within the complex. A principal reason for such "in-house" funding is the desire to avoid possible conflicts of imterest that might arise if a mutual fund complex managed its employee benefit plan separately from its publicly held mutual funds. The SEC has therefore encouraged mutual funds to fund "m-house" plans with mu-

27. For example, the investment by a plan in a pooled investment fund maimtained by a bank or in a separate account of an insurance company that is not a registered investment company may cause the bank or insurance company to become a fiduciary and the assets of the fund or account to become plan assets. See H.R. CoNF. REP. 296. Each plan having an interest in the pooled fund or separate account will have a wide number of parties in interest and disqualified persons; the prohibited transaction provisions of ERISA and the Code may prohibit the bank or insurance coinpany froin causing the pooled fund or account to enter imto a transaction with any of these persons. The Department of Labor issued a prohibited transaction exemption for the insurance industry, 43 Fed. Reg. 59,915 (1978), and has proposed an exemption for the banking industry. See 44 Fed. Reg. 44,290 (1979).

28. See note 2 supro and accompauying text.

29. See Oversight Hearings, supra note 2, at 777 (statement of Investment Company Institute).

30. ERISA $\S 408$ (a) and I.R.C. $\S 4975$ (c)(2) permit the Agencies to grant administrative exemptions on both individual and class bases. For a general discussion, see Mamorsky \& Murphy, What Every Fiduciary Should Know: Exemptions to the Prohibited Transactions Rules, Pension WORLD, Oct. 1978, at 58. 
tual fund shares. ${ }^{31}$ Because ERISA expressly excludes such arrangements, ${ }^{32}$ the Investment Company Institute sought an exemption from the provision. In response, the Agencies promulgated Prohibited Transaction Exemption 77-3,33 which permits the funding of an "imhouse" mutual fund plan with shares of the mutual fund so long as the plan satisfies the following conditions: (1) the plan must not pay a sales commission; (2) the plan must not pay a redemption fee other than to the mutual fund itself; (3) the plan must not pay a separate investment management fee, imvestment advisory fee or any similar fee; and (4) the plan's relationship with the mutual fund complex must be on a basis no less favorable to the plan than its relationship with other shareholders of the fund.

\section{B. Investment Advisers.}

A large number of imvestinent advisory firms render investment advice both to inutual funds and to other clients, including a wide variety of employee benefit plans. ${ }^{34}$ Many of these firms often recommend that a portion of a plan's assets be invested in one or more of these mutual funds. This may be appropriate, for example, where the mutual fund's portfolio consists of securities of smaller, more aggressive growtl companies or securities of foreign issuers that might not be appropriate imvestments for the plan on an individualized basis. Similarly, at times it nay be appropriate for the plan to invest a portion of its assets in slort-term money market instruments, and it often may be preferable for the plan to invest in a mutual fund that lias a diversified portfolio consisting of such imstruments rather than to purchase the imstruments on an imdividual basis. In order to avoid having the client pay what would amount to a double advisory fee, the portion of the client's assets that is imvested in the mutual fund is deducted from the asset base on which the adviser computes its private advisory fee. ${ }^{35}$

31. Under the Investment Company Act of 1940, 15 U.S.C. $\$ \S 80 \mathrm{a}-1$ to -52 (1976), and Rule 22d-1 promulgated thereunder, 17 C.F.R. $\$ 270.22 d-1$ (1978), a mutual fund that is normally sold with a sales charge may reduce or eliminate this charge in counection with sales to full-time employees of the mutual fund, to its investment adviser and primcipal underwriter and to employee benefit plans covering such individuals. The SEC staff has issued an interpretive letter expanding the coverage of this exemption. Investment Coinpany Institute, [1976-1977 Transfer Bimder] FeD. SEC. L. REP. (CCH) I 80,671.

32. ERISA § 406(a), (b)(2). In contrast, as indicated in note 22 supra, ERISA expressly permits "in-house" plans of banks and insurance companies to invest in deposits of the bank or insurance policies written by the insurance company.

33. $1977-1$ C.B. 360 .

34. See Feimberg, Can Mutual Funds Make It as Pension Managers?, Pension ManageMENT, Oct. 1978, at 143.

35. See SEC No-action letter, Wellington Management Co. (June 21, 1972). 
The practice of an investment adviser to an einployee benefit plan causing the plan to invest in a mutual fund managed by that adviser may raise problems with regard to prohibited transactions. ${ }^{36}$ The investment adviser to the plan is clearly a fiduciary and hence is a party in interest or disqualified person with respect to the plan. ERISA's special inutual fund provisions do not change this result. While the plan's purchase of shares of the mutual fund may not raise any prohibited transaction problems (since the transaction is between the plan and the inutual fund, which is not a party in interest or disqualified person), the advisory fee arrangement arguably inay involve a possible conflict of interest on the part of the investment adviser-fiduciary. For example, since the advisory fee paid by the inutual fund normally varies with the size of the fund, it may be in the interest of the adviser to increase the size of the inutual fund by causing the plan to invest in the fund.

In order to resolve this issue, a group of investment advisory firms sought and obtained Prohibited Transaction Exemption 77-4, ${ }^{37}$ which permits this type of transaction, provided the following conditions are met: (1) the plan must not pay a sales commission; (2) the plan inust not pay a redemption fee other than to the inutual fund itself; (3) the plan inust not pay an investment management fee, an investment advisory fee or any similar fee with respect to plan assets invested in the inutual fund; and (4) an independent fiduciary of the plan who has received full information froin the adviser inust approve the arrangeinent in advance. ${ }^{38}$

\section{Master and Prototype Plans.}

The Internal Revenue Service has promulgated procedures that permit inutual funds to sponsor master and prototype corporate plans, Keogh plans and Individual Retirement Accounts (I.R.A.s) whose forms inay be approved in advance by the Internal Revenue Service. ${ }^{39}$

36. In contrast, as indicated in note 22 supra, ERISA expressly permits a bank or insurance company to invest the assets of a plan that it advises in a pooled fund maintained by the bank or insurance company.

37. 1977-1 C.B. 362.

38. This exemption was the first in which the Agencies conditioned an administrative exeinption on approval by an independent plan fiduciary. Subsequently the Agencies have followed this approach in connection with other exemptions. See, e.g., Prohibited Transaction Exemption 77-9, 1977-2 C.B. 428, discussed in text accompanying notes 55-56 infra. It is interesting to note that this is also the approach followed in $\S 15(\mathrm{c})$ of the Investment Company Act of 1940 , 15 U.S.C. $\S 80 \mathrm{a}-15$ (c) (1976), requiring approval of mutual fund investment advisory contracts by independent fund directors.

39. See Rev. Proc. 75-52, 1975-2 C.B. 592 (corporate); Rev. Proc. 75-51, 1975-2 C.B. 590 (Kcogh); Rev. Proc. 75-6, 1975-1 C.B. 646 (I.R.A.). Master and prototype plans are designed to permit sinaller employers and other persons, e.g., participants in Individual Retirement Accounts, 
Discussions between the Investment Company Institute and staff officials of the Agencies evidenced concern that the sponsor of a master or prototype plan might be considered to be a fiduciary, particularly simce the sponsor normally retains the power to amend the master or prototype plan. ${ }^{40}$ Therefore, the Investment Company Institute requested an interpretation or, alternatively, a class exemption. ${ }^{41}$ In response, the Agencies issued Prohibited Transaction Exemption 77-9,42 which permits mutual fund sponsors of master and prototype plans to continue to sell inutual fund shares to such plans and to redeem shares owned by the plans, provided the following conditions are satisfied: (1) the transaction must be in the ordinary course of busmess; (2) the transaction must be on terms at least as favorable to the plan as an arm's length transaction with an unrelated party; and (3) the total consideration received by the mutual fund's principal underwriter and the selling broker-dealer must not exceed reasonable compensation.

\section{Non-Bank Trustees and Custodians.}

Prior to the enactment of ERISA, the Code provided that only a bank could serve as the trustee or custodian for Keogh plan funded with mutual fund shares. ${ }^{43}$ This requirement did not present any operational difficulties when the Keogh legislation was enacted im 1962, since at that time most mutual funds employed banks to serve as their transfer agents and to perform necessary accounting and recordkeeping relating to shareholder accounts. It was, therefore, logical for a Keogh plan funded with mutual fund shares to retain the mutual fund's bank transfer agent to serve as the plan's trustee or custodian. However, over the last decade a large number of mutual fund organizations have

to establish plans on a simplified and economical basis through the adoption of a standard model plan that has received IRS approval as to form.

40. This problem is not unique to mutual funds; it also affects other sponsors of master and prototype plans, including banks and insurance companies. See Oversight Hearings, supra note 2, at 684 (statement of M. John Lippman on behalf of the International Trust Corporation); PaneI Discussion, Special Problems of Insurance Companies, 31 Bus. LAw. 257, $264-67$ (1975).

41. Subsequent to the filing of the Institute's submission, the Agencies issued the so-called "inultiple service regulations." 29 C.F.R. § $2550.408 b-2$ (1978). The regulations appear to indicate that if sponsors of master and prototype plans are merely parties in interest or disqualified persons by reason of providing services to employee benefit plans, their activities will not be barred by ERISA's prohibited transaction provisions. However, the regulations do not deal with the case where the sponsor may be considered to be a fiduciary. But see IRS Private Letter Ruling 7837048, [1978] FED. TAXES PRIV. LTR. RUL. (P-H) [ 3214(78), that stated that $X$, the sponsor of a master Keogh plan, is a fiduciary with respect to the plan because it has reserved the right to amend or terminate the plan and because it has the authority to appoint or remove the trustees.

42. 1977-2 C.B. 428 ; 44 Fed. Reg. 1479 (1979).

43. I.R.C. $\$ 401(d)$, as added by the Self-Employed Individuals Tax Retirement Act of 1962, Pub. L. No. 87-792, 76 Stat. 809, effective for taxable years beginning after December 31, 1962. 
ceased using banks as their transfer agents. A number of these organizations currently employ non-bank data processing companies wholly unrelated to the fund complex. In other situations, the transfer agent's function is performed by the mutual fund itself, or by the fund's imvestment adviser, primcipal underwriter or an affiliate thereof.

ERISA amended the Code to provide that entities other than banks could serve as trustees or custodians for Keogh plans, I.R.A.s and programs establislied under section $403(\mathrm{~b})(7)$ of the Code. ${ }^{44} \mathrm{~A}$ number of mutual fund organizations that perform their own transfer agent work liave expressed an interest in servimg as non-bank trustees or custodians for plans funded with shares of their mutual funds. While at least one court has held that a nondiscretionary custodian is not a fiduciary, ${ }^{45}$ the Agencies have not taken a formal position on this matter. Therefore, the Investment Company Institute submitted a request for an interpretation or, alternatively, a class exemption. The Department of Labor lias not yet acted on this request, presumably due to the fact that only a few mutual fund organizations are presently serving as trustees or custodians for plans funded with shares of their mutual funds. However, the Agencies did modify Prohibited Transaction Exenuption 77-9 to permit sponsors of master and prototype plans to serve also as nondiscretionary trustees and custodians. ${ }^{46}$

\section{E. Broker-Dealers.}

As noted above, inany mutual fund organizations sell shares of their mutual funds to investors through broker-dealers that are unaffiliated witl the mutual fund complex. While ERISA contams special statutory provisions for various types of financial institutions, including inutual funds, banks and insurance companies, it is silent with respect to activities performed by broker-dealers. ${ }^{47}$ This omission did not concern the mutual fund industry at the time ERISA was enacted, because the industry believed that a broker-dealer recommending and selling mutual fund shares to employee benefit plans would not be a classified as a fiduciary. Section 3(21)(A) of ERISA and parallel section 4975(e)(3) of the Code define the term "fiduciary" to imclude a person who "renders investment advice for a fee or other compensation, direct

44. See ERISA $\S \S 1022(d)-(e), 2002(b)$.

45. Hibernia Bank v. Internatioual Bhd. of Teamsters, 411 F. Supp. 478, 490. (N.D. Cal. 1976).

46. 44 Fed. Reg. 1479 (1979).

47. "The conferees did not grant a statutory exemptiou to brokers for this type of multiple service because of the difficulty of establishing precise statutory standards for protecting against potential abuses." H.R. CONF. REP. 309-10. 
or indirect, with respect to any moneys or other property of such plan." 48 Commissions received by a broker-dealer on the sale of mutual fund shares are fixed by the fund in its prospectus ${ }^{49}$ and do not fluctuate with the amount of investment advice or other services the broker-dealer renders to an investor purchasing shares of the inutual fund. The industry therefore believed that a broker-dealer who recommended and sold fund sliares to a plan would not be a fiduciary, since the broker-dealer was not compensated for mvestment advice. ${ }^{50}$ However, while the Agencies have not issued a formal regulation or interpretation regarding this matter, they liave indicated a contrary view. ${ }^{51}$

The failure of ERISA to exempt statutorily transactions by brokerdealer fiduciaries led the broker-dealer industry to request and obtain Prohibited Transaction Exemption 75-1.52 Part II of this class exemption permits a broker-dealer fiduciary to sell inutual fund shares to employee plans. This part was based to some extent on the existence of regulations under the federal securities laws. ${ }^{53}$ However, the exeinption expressly excludes the situation in which "a fiduciary with respect to the plan is . . . a principal underwriter for, or affiliated with," 54 the mutual fund in question. Thus, the apparent effect of the exemption is to exempt sales of mutual fund slrares by broker-dealers that are unrelated to the mutual fund complex, but not to exempt sales by a inutual fund organization's own sales force. This distimction has never been officially explained by the Agencies, but apparently results from concern that a salesman employed by a particular mutual fund organization is likely to be less dismterested than a broker-dealer that sells shares of mutual funds sponsored by organizations unrelated to the

48. ERISA § 3(21)(A); I.R.C. § 4975(e)(3).

49. 15 U.S.C. $\$ 80 a-22(d)(1976)$.

50. This view was supported by $\S 202(11)$ (c) of the Investment Advisers Act of 1940, 15 U.S.C. $\S 80 \mathrm{~b}-2(11)$ (c) (1976), which excludes from the definition of investment adviser "any broker or dealer whose performance of such [investment advisory] services is solely incidental to the conduct of his businesses as a broker or dealer and who receives no special coinpensation therefore." Id.

51. In announcing Labor Regulation $\S 2510.3-21,29$ C.F.R. $§ 2510.3-21$ (1978), the Department of Labor declined to issue a definitive ruling on what constituted a fee or compensation for the rendering of investment advice; it stated, however, that direct or indirect compensation "should be deemed to include all fees or other compensation incident to the transaction in which the investment advice . . has been rendered or will be rendered. This inay include, for example, brokerage commissions, mutual fund sales commissions, and insurance sales commissions." 40 Fed. Reg. 50,842 (1975). For further discussion, see Groom \& Mazaway, ERISA-Fiduciary Responsibility, U. So. CAL. L. Center Twenty-Eighth TAX Inst. 982-84 (1976); Page, Fiduciary Responsibility: Limitations on Fiduciary; Potential Liability Problems; and Selecting a Fiduciary, N.Y.U. THIRTY-FouRTH ANN. INST. ON FED. TAX. 1186-91 (1976).

52. 1975-2 C.B. 543 . See also 44 Fed. Reg. 5963 (1979).

53. $1975-2$ C.B. $543,544$.

54. Id. 547. 
broker-dealer.

The exclusion of mutual fund direct sales forces from Prohibited Transaction Exemption 75-1 led the Investment Company Institute and a group of mutual fund organizations to seek further relief, which was granted in Prohibited Transaction Exemption 77-9.55 This class exemption permits mutual fund direct sales forces to recommend and sell mutual fund sliares to employee benefit plans, provided the following conditions are met: (1) the transaction must be in the ordinary course of business; (2) the transaction must be on terms at least as favorable to the plan as an arm's length transaction with a third party; (3) the total consideration received must not exceed reasonable compensation; (4) appropriate disclosure must be made to an independent plan fiduciary; and (5) the independent fiduciary must give prior approval to the transaction. ${ }^{56}$

\section{Plan Investment in Mutual Fund Shares}

Prior to the enactment of ERISA, mutual funds were recognized as a suitable imvestment vehicle for a wide variety of employee benefit plans, notably plans maintamed by small corporations and self-employed individuals. ${ }^{57}$ ERISA not only expressly expanded the type of employee benefit plans that can be funded witli mutual fund shares, ${ }^{58}$ but, by imposing fiduciary duties on sponsors of employee benefit plans, has encouraged imvestment in mutual funds simce tliey provide liquidity, professional management and diversification of assets. ${ }^{59}$ The

55. $1977-2$ C.B. 428.

56. One of the requirements of the exemption as originally adopted was that an independent plan fiduciary, following receipt of required disclosure material and prior to the execution of each transaction, acknowledged in writing receipt of such information and approve the transaction on behalf of the plan. See 43 Fed. Reg. 18,359, 55,005 (1978). This condition created interpretive problems, since each purchase of mutual fund shares may be regarded as a separate transaction requiring the independent plan fiduciary to approve the transaction and acknowledge receipt of disclosure information on a continuous basis (that is, before every reinvested dividend). At the Investment Company Institute's urging, the exemption was amended to completely delete the acknowledgement requirement. In addition, the exemption was modified to provide that a inutual fund direct sales force may generally presume from the failure of the independent fiduciary to discontinue purchasing shares of the fund that such fiduciary has approved the transaction. See 44 Fed. Reg. 1479, 1483 (1979).

57. The origimal Keogh legislation enacted in 1962 expressly provided that inutual fund shares could be used to fund Keogh plans held in custodial accounts. I.R.C. $\S 401(\mathrm{f})$. Mutual funds are the largest funding inedium for Keogh plans. See BoArd of GoverNors of tHe Federal Reserve System, Individual Retirement Accounts and Keogh Accounts at SeLECTED FinANCIAL INSTITUTIONS AS OF MARCH 31, 1976, at 2 (1976).

58. See, e.g., I.R.C. $\S 403(\mathrm{~b})(7)$ (relating to plans of public school systems and certain charitable organizations).

59. See, e.g., Davies, Feeling Becomes Mutual for Small Pension Plans, Pensions \& Investments, Jan. 30, 1978, at 28, col. 1; DeViney, Rebounding Mutual Funds Entice Pension Dollars, 
Investment Work Group of the ERISA Advisory Council has concluded that "the purchase of . . . mutual fund shares . . . may provide benefits similar to naming qualified professional investment managers and may be particularly beneficial for smaller plans in meeting the prudence and diversification standards of ERISA." 60

As discussed above, ${ }^{61}$ the normal relationship between a inutual fund and an employee benefit plan that has invested in the fund will not cause the mutual fund, its investunent adviser or principal underwriter to assume fiduciary status under ERISA. This has led some observers to speculate that sponsors of employee benefit plans, particularly sponsors of larger plans, may be reluctant to invest in mutual fund shares smce this will not result in a spreading of fiduciary responsibility. ${ }^{62}$ Under this theory, a sponsor should seek to limit his fidicuiary liability by allocating or delegating his responsibility to an mvestment manager. ${ }^{63}$

While the author is unaware of any cases in which this problem has actually arisen, it should be noted that there are a number of ways to allay fears on the part of plan sponsors investing in mutual fund shares. First, it may be possible for the sponsor of an einployee benefit plan to appoint the investment adviser in a mutual fund complex to serve as the plan's imvestment manager. Under this arrangement, the adviser who accepts such appoimtment may invest the plan's assets in one or more of the mutual funds managed by the adviser. This type of arrangement is expressly permitted by Prohibited Transaction Exemption 77-4 $\mathrm{m}$ the case of no-load funds ${ }^{64}$ and by Prohibited Transaction

Pensions \& Investments, July 19, 1976, at 6, col. 1; Fullerton, Mutual Funds Offer Advantages to Large and Small Pension Funds, Pensions \& Investments, Oct. 10, 1977, at 21, col. 2. It is interesting to note that the concept of market or index funds stemmed from an analysis of investment in mutual funds. See Langbein \& Posner, Market Funds and Trust-Investment Law, 1 AM. B. FouNDATION RESEARCH J. 1 (1976).

60. ERISA Advisory Council, Report of the Investment Work Group 5 (1976).

61. See text accompanying notes 23-25 supra.

62. See, e.g., Rohrer, Large Plans Still Leery of Mutual Funds, Pensions \& Investments, June 5,1978 , at 32, col. 1 .

63. ERISA $\S 402(\mathrm{e})(3)$ provides that a named fiduciary of a plan who has control or management responsibilities over the plan assets may appoint an "investment manager," a term that is defined in ERISA \& $3(38)$ as a fiduciary:

(A) who has the power to manage, acquire, or dispose of any asset of a plan;

(B) who is (i) registered as an investment adviser under the Investment Advisers Act of 1940; (ii) is a bank, as defined in the Act; or (iii) is an insurance company qualified to perform services described in subparagraph $(A)$ under the laws of more than one State; and

(C) has acknowledged in writimg that he is a fiduciary with respect to the plan. Id. If an investment manager is properly appointed, ERISA $\$ 405$ provides that the plan fiduciary is no longer responsible for individual investment decisions made by the inanager. See Hutchinson, The Compleat Fiduciary, Pension WorLd, Apr. 1978, at 46, 48.

64. See text accoinpanying notes 34-38 supra. 
Exemption 77-9 in the case of funds with sales charges. ${ }^{65}$ Some mutual fund complexes are currently offering this type of service ${ }^{66}$ and others are reportedly considering initiatimg such an arrangement. ${ }^{67}$

Second, it is possible for the sponsor of an employee benefit plan to appoint an investment manager who is unrelated to a mutual fund complex and for the manager then to cause the plan to invest in shares of one or more mutual funds. This type of arrangement is extremely common and avoids the entanglements of the prohibited transaction provisions, since the mutual fund organization does not become a party in interest or disqualified person with respect to the plan.

Third, it is likely that many employee benefit plans funded with mutual fund shares will qualify for special treatment under section 404(c) of ERISA, which provides that if each participant in a plan is pernitted to select his own investments from among a broad range, the employer will not be responsible for the employee's investment decisions. $^{68}$ This section is designed to allow cach participant in an individual account plan to determine his own investment objectives and level of risk. While the employer inust choose the particular financial institution that offers a "broad range of investments," each participant specifies the division of his account between such investments. Since many mutual fund complexes sponsor a large number of mutual funds with varying investment objectives-ranging from funds investing in short-terin inoney market imstruments to funds invcsting in growth stocks-it appears likely that plans that permit participants to select their own investments froin among these various funds will qualify under section 404(c) of ERISA. ${ }^{70}$

65. See text accompanying notes 55-56 supra.

66. See Advertisement by The Mutual Life Insurance Company of New York, Pension WORLD, Sept. 1978, at 25.

67. See DeViney, supra note 59.

68. ERISA § 404(c).

In the case of a pension plan which provides for individual accounts and permits a participant or beneficiary to exercise control over assets in his account, if a participant or beneficiary exercises control over the assets in his account (as determined under regulations of the Secretary)-(1) such participant or beneficiary shall not be deeined to be a fiduciary by reason of such exercise, and (2) no person who is otherwise a fiduciary shall be liable under this part for any loss, or by reason of any breach, which results from such Id. participant's or beneficiary's exercise of control.

For a general discussion, see Note, Fiduciary Standards and the Prudent Man Rule Under the Employment (sic) Retirement Income Security Act of 1974, 88 HARV. L. REv. 960,974 (1975). See also Lippman, "Earmarked" Trust Accounts-A Solution to the Small Employer's Fiduciary Responsibilities, 3 J. Pension Plan. \& Compliance 210 (1977).

69. H.R. CONF. REP. 305-06.

70. The Department of Labor has not yet issued regulations under ERISA \& 404(c). On June 15, 1978, the Investment Company Institute requested that such regulations be issued forthwith. 
Fourth, it is doubtful that the sponsor of an employee benefit plan is in a very different position under ERISA whether he selects an investinent inanager or invests in shares of one or more mutual funds. It is clear that plan sponsors are under a duty to act prudently both in initially selecting an investment manager and in continuing the use of the inanager. ${ }^{71}$ This provision has been imterpreted to require plan fiduciaries to monitor continually the performance of investment managers. ${ }^{72}$ The Department of Labor has issued an interpretative opinion indicating that plan fiduciaries unust follow similar procedures when investing in nutual fund shares. ${ }^{73}$ Indeed, it is likely to be far easier for a plan fiduciary to nionitor the performance of a inutual fund than that of an investinent manager. For while the federal securities laws require inutual funds to provide shareholders with current financial information in the form of current prospectuses, annual proxy statements and semi-annual reports, similar requirements are not imposed on in-

See also Oversight Hearings, supra note 2, at 460-61 (statement of Bernard F. Curry on behalf of the American Bankers Association).

71. See H.R. CONF. REP.,301-02.

Under the substitute, if the plan so provides, a person who is a named fiduciary with respect to the control or management of plan assets may appoint a qualified investment manager to manage all or part of the plan assets. (However, in choosing an investment manager, the named fiduciary must act prudently and in the interests of participants and beneficiaries, and also must act in this manner in continumg the use of an investment manager.)

Id.

72. ERISA Interpretive Bulletin 75-8 states:

FR-17 Q: What are the ongoing responsibilities of a fiduciary who has appointed trustees or other fiduciaries with respect to these appointments:

A: At reasonable intervals the performance of trustees and other fiduciaries should be reviewed by the appointing fiduciary in such manner as may be reasonably expected to ensure that their performance hás been in comphance with the terms of the plan and statutory standards, and satisfies the needs of the plan. No single procedure will be appropriate in all cases; the procedure adopted may vary in accordance with the nature of the plan and other facts and circumstances relevant to the choice of the procedure.

29 C.F.R. $\$ 2509.75-8$ (1978). In addition, the Report of the Investment Work Group of the ERISA Advisory Council stated: "The . . . fiduciary should monitor and evaluate the performance of the . . . investment manager ... and periodically decide whether or not to retain the ... investunent manager." ERISA ADViSORY CouNCIL, supra note 60, at 6.

73. Dep't of Labor Interpretative Opinion Letter 75-92, at 2-3, Nov. 4, 1975 (on file at Duke Law Journal office). That Opinion Letter states:

[I]f a plan . . f fiduciary is considering whether to invest the entire amount of plan assets, or any part thereof, in shares of a mutual fund, such . . . fiduciary should examine the securities and other assets held by the mutual fund before such investment is made, review the statement as to the fund's investment policy as contaimed in the fund's prospectus, and periodically review the fund's investments whenever such information is made available, as long as plan assets are invested in such shares, to determine whether the investment, when considered together with other plan investments, if any, meets the diversification requirements. ... .

Such . . . fiduciary should also examine the features of such mutual fund in the light of the particular objectives of the plan, to determine whether investment of plan Id. assets in shares of the mutual fund ineets the other requirements of section 404(a)(1). 
vestment managers. ${ }^{74}$ In fact, investment advisers to mutual funds are attracting pension plan clients for individual management based on the performance records of their publicly offered inutual funds. ${ }^{75}$

Finally, the traditional agreement between a plan and an investinent adviser includes certain investment mstructions and objectives established by the plan fiduciary that the investment adviser is bound to honor. ${ }^{76}$ Thus, the plan fiduciary will bear the ultimate reponsibility in choosing the investment objectives of the plan. Without increasing his responsibility, the plan fiduciary can seek a mutual fund with concomitant investment objectives. This should not present a difficult task, since in recent years a plethora of inutual funds have been created that meet nearly all investment objectives.

\section{Conclusion}

Since the enactment of the federal securities laws, particularly the Investment Company Act of $1940,{ }^{77}$ inutual funds have been subject to extensive substantive regulation on the national level. In enacting ERISA, Congress recognized this system of federal regulation and exeinpted inutual fund organizations from the Act's provisions relating to prohibited transactions. Therefore, the inutual fund industry and the investment dealers that offer inutual fund shares have not encountered the severe problems that have confronted other types of financial institutions serving employee benefit plans. At the same time, ERISA's requirements of prudence and diversification have encouraged the use of mutual funds as a funding medium for a wide variety of employee benefit plans. It appears likely that future pension legislation will serve to increase further employee benefit plan investment in mutual fund shares. $^{78}$

74. For a discussion of the difficulties in obtaining performance information concerning investmcnt managers, see Schotland, Picking Investment Managers: Eight Observations From One Who's Been There, Pensions \& Investments, Apr. 24, 1978, at 61, col. 1.

75. See Feimberg, supra note 34 .

76. If such instructions are contrary to the plan instrument or are clearly imprudent on their face, the investment adviser may reject the instructions. "In this case, if the trustee properly follows the instructions of the named fiduciaries, the trustee generally is not to be liable for losses which arise out of following these instructions." H.R. CONF. REP. 302 (emphasis added). The use of the word "generally" implies that under some circumstances the trustee would indeed be liable.

77. 15 U.S.C. $\$ \S 80 \mathrm{a}-1$ to -52 (1976).

78. Senators Williams and Javits introduced a comprehensive ERISA reform bill in 1978. S. 209, 96th Cong., 1st Sess. (1979), reprinted in The ERISA Improvements Act of 1979: Hearings on S. 209 Before the Senate Comm on Labor and Human Resources, 96th Cong., 1st Sess. (1979). Title IV of the bill would establish a new system of "Special Master and Prototype Plans" that could be sponsored by limited types of financial institutions, including inutual fund organizations. 